\title{
Use of MUF Resin for Improving the Wheat Protein Binder in Particle Boards Made from Agricultural Residues
}

\author{
Neda Nikvash ${ }^{1}$, Markus Euring ${ }^{1} \&$ Alireza Kharazipour ${ }^{1}$ \\ ${ }^{1}$ Faculty of Forest Science and Forest Ecology, Buesgen-Institute, Department of Molecular Wood \\ Biotechnology and Technical Mycology, Georg-august-University of Goettingen, Göttingen, Germany \\ Correspondence: Alireza Kharazipour, Faculty of Forest Science and Forest Ecology, Buesgen-Institute, \\ Department of Molecular Wood Biotechnology and Technical Mycology, Georg-august-University of Goettingen, \\ Büsgenweg 2, Göttingen 37077, Germany. E-mail: akharaz@gwdg.de
}

Received: January 15, 2013 Accepted: February 16, 2013 Online Published: March 24, 2013

doi:10.5539/jmsr.v2n2p126 URL: http://dx.doi.org/10.5539/jmsr.v2n2p126

\begin{abstract}
This work was focused on the production and characterization of lightweight and water resistance particle boards with various lignocellulosic materials of the annual plants hemp (Cannabis sativa L.), canola (Brassica napus L.) and bagasse (Saccharum officinarum L.) in admixtures with industrial wood. Some chemical properties of these annual plants were investigated to find out their chemical characteristics in wood composites production. In all board variants $100 \%$ of the middle layers consisted of chips from one of the above annual plants. Reference boards were $100 \%$ beech wood. Laboratory manufacturing treatments included two panel density levels (500 and $600 \mathrm{~kg} / \mathrm{m}^{3}$ ) and three resin types (urea-formaldehyde, melamine-urea-formaldehyde and wheat protein).

Water absorption and thickness swelling of the laboratory manufactured boards were improved by adding melamine to urea-formaldehyde resin and by adding water repellent chemicals. The mechanical properties of the boards produced met the requirement for the general purpose product standards (EN 312-2) at both 500- and $600-\mathrm{kg} / \mathrm{m}^{3}$ densities. Decreasing the density, negatively affected the bending (modulus of rupture) and internal bond properties of canola boards. This decreasing trend was also observed for modulus of rupture values in bagasse boards of $500 \mathrm{~kg} / \mathrm{m}^{3}$ density.

Based on the results of the chemical analysis, it might be concluded that high values of ash content and lower values of hemicellulose and lignin content caused low physical properties and/or high water absorption of canola boards. The findings indicated that hemp and bagasse are valuable renewable natural resources for particleboard production and could be utilized as a substitute for wood in board production. In comparison with the reference boards, mixed variants boards showed surprisingly good results and generally conformed to European standards (EN 312-2) values.
\end{abstract}

Keywords: wheat protein, melamine-urea-formaldehyde resin, particle board, canola, bagasse, hemp, chemical properties, physical properties

\section{Introduction}

In recent years there has been increasing social pressure and a growing demand among consumers and manufacturers for environmental and ecological friendly alternatives (OECD, 2008). Economic development and population expansion have caused great increases in competition for wood and wood products (FAOSTAT, 1998). Decreasing capacity of the world's forests (McNutt et al., 1992) to produce wood fiber on the one hand and deficits in wood and wood fiber on the other hand have led to many research and industrial efforts to find alternative lignocellulosic sources as raw material. Several alternative solutions have been reported by the Resource Conservation Alliance (RCA, 2003). One of the alternative ways is to stop denuding the forest land. In Germany the decline in forest resource is due to the withdrawal of forest areas from industrial production for other uses such as recreational areas (IUCN, 1994). Some important sources of lignocellulosic raw materials include wood recycling, plantation fast-growing wood species, annual fibrous plants and agricultural residues utilization. The utilization of annual plants has many advantages, such as widespread growth regions, plentiful supply, widely accessible, and renewable, sometimes up to three times per year. During the last century the pulp and composite panel industries started utilizing agricultural by-products and wastes as raw materials, despite the high cost of collecting, storing and transporting the plant residue materials. 
In this study hemp, canola and bagasse as lignocellulosic raw material were selected. After bamboo, hemp is the world's second fastest growing plant (Wikipedia, 2011), potentially shooting up four meters in just 14 weeks, rapidly taking carbon from the air (Dewey, 1916). Canola is an agricultural residue, available in huge amounts in Europe, Canada and many other countries, with potential for plant fiber. Also, bagasse (megass), a fiber remaining after the extraction of the sugar-bearing juice from sugarcane, is a valuable fiber by-product. A sugar factory produces nearly $30 \%$ wet bagasse fiber (by weight) after sugarcane is crushed (Rasul et al., 1999). To meet the future demand and to overcome the wood shortages, use of the above plant fiber by-products are strongly encouraged. Many studies have been conducted to utilize agricultural plant-fiber residues in the forest product industry as raw material components in composite products in several countries (Nikvash et al., 2010).

Resin binders are one of the important factors affecting mechanical and physical properties of particleboards. Urea-formaldehyde (UF) and phenol-formaldehyde (PF) resins are commonly used in the composite sector of the forest products industry (Zucaro \& Reen, 1995). It is well known that formaldehyde emission from UF- and some PF-bonded boards can potentially cause environmental problems (Roffael, 1993), although, in recent years such potential emissions have been neutralized or substantially reduced.

The advantages of UF resins are low cost, water solubility, easy use (under a wide variety of curing conditions), relatively low cure temperature, microorganisms resistance, low abrasion hardness, excellent thermal properties, and clear or light color (especially of the cured resin). Due to these advantages, the wood composite industry utilizes UF as a common resin, worldwide. The main disadvantage UF resin is the lack of resistance to high moisture conditions, especially in combination with heat. These conditions lead to a reversal of the bond forming reactions of UF and consequently the potential emission of formaldehyde (Pizzi et al., 1994). The bond forming reactions of UF resins are catalyzed by acid catalyst that hasten bond cure, but these reactions can also increase the rate of hydrolysis and formaldehyde liberation.

There are several methods for reduction of formaldehyde emission levels from wood based products bonded with UF resin. Recently, renewed interest has increased in the utilization of natural resins instead of synthetic resins for bonding wood composites (Nikvash et al., 2012, 2013). Generally, natural adhesives have to be modified for improved water resistance and mechanical properties before utilization in modern particle board manufacture. There are reported several methods to improve the adhesion properties of natural adhesives. For instance, modification of natural adhesives with urea, citric acid, boric acid or sodium hydroxide provide denaturing and disulphide bond cleavage (Kalapathy et al., 1997); also, crosslinking, acylation, and oxidation are realistic methods as well (Lambuth, 1977). In a previous study, modified wheat protein (WP) with urea was utilized to reduce formaldehyde emission of the UF resin binder, but the study panels exhibited poor physical properties, particularly in water absorption and thickness swelling (Nikvash et al., 2012). This study examined MUF resin for water absorption and water swelling improvement. Little published information has been found on the use of annual plants in particle boards using MUF-wheat protein (WP) binder.

The chemical constituents of woody plant biomass are important factors which play a key role in original plant properties and their end-products. It is necessary to determine the amounts of cellulose, hemicellulose, lignin, extractives and ash in plant raw materials before utilizing the materials and for characterizing of end product particle board properties.

This research aimed to characterize mechanical and physical properties of the particleboards. Some chemical properties of the annual plants used in the board manufacture were investigated. Furthermore, adding WP to MUF resin was considered as an environmental-friendly resin binder.

\section{Material and Methods}

Hemp and canola were collected from the field in Germany and dried agricultural residues of bagasse were brought from Iran. The industrial beech wood particles were supplied from a particle board factory located in Guetersloh, Germany. The residues were chipped and screened to gain thin, homogeneous and appropriate particle material. Chemical analyses of some chemical compounds were utilized to accomplish related protocols, including the amount of lignin, hemicellulose, pentose, extractives, as well as the ash contents. For this purpose, specimens were sampled and prepared according to Tappi test method T 257 om-85 (Milne et al., 1990). Pentose and hemicellulose contents were determined according to the Jame and Büttel (1968) method by measuring the amount of furfural content in pentose. Lignin content was measured by Halse's (1926) modified method. The extractives content of the sample materials was determined according to the TAPPI test method T 204 om- 88 . Ash content was analyzed by Tappi test method T $211 \mathrm{om}-93$. Screened raw material to produce particle boards was dried to $3 \%$ moisture content at $110-120^{\circ} \mathrm{C}$, oven-dry basis. Binder adhesives included UF, MUF and WP in particle board production (Table 1). 
Table 1. The properties of adhesives

\begin{tabular}{|c|c|c|c|c|}
\hline \multicolumn{2}{|l|}{ Properties } & UF & MUF & WP \\
\hline \multicolumn{2}{|l|}{ Appearance } & Milky & Milky turbid & Loosely chocolate \\
\hline \multicolumn{2}{|l|}{$\mathrm{pH}$} & $7.5-9.5$ & $9.4-10.0$ & 3.5 \\
\hline \multicolumn{2}{|l|}{ Viscosity } & $350-600$ & $150-400$ & $260-350$ \\
\hline \multicolumn{2}{|l|}{ Density } & $1.28-1.30$ & $1.29-1.30$ & $1.2-1.23$ \\
\hline \multicolumn{2}{|l|}{ Solids } & $66.5 \pm 1$ & $65 \pm 1$ & $50 \pm 1$ \\
\hline \multicolumn{2}{|c|}{ Free formaldehyde $\left(\mathrm{mL} / \mathrm{m}^{3}, \mathrm{ppm}\right)$} & 0.1 & 0.1 & - \\
\hline \multicolumn{2}{|c|}{ Water tolerance ratio } & & $10 / 27$ & $10 / 20$ \\
\hline \multirow[t]{2}{*}{$40 \%\left(\mathrm{NH}_{4}\right)_{2} \mathrm{SO}_{4}$ content } & $(\%)$ & & & - \\
\hline & & $\mathrm{SL}^{*-1}, \mathrm{ML}^{*-2}$ & $\mathrm{SL}^{-1}, \mathrm{ML}^{-2}$ & \\
\hline Gel point $100^{\circ} \mathrm{C}$ & (s) & $25-30$ & & - \\
\hline Storage time $20^{\circ} \mathrm{C}$ & (weeks) & $61 / 2-9$ & $6-10$ & $6-9$ \\
\hline Flowing point $25^{\circ} \mathrm{C}$ & (s) & $20-40$ & $20-40$ & - \\
\hline \multirow[t]{2}{*}{ Binder percentage } & $(\%)$ & 100 & 0 & 0 \\
\hline & ML & 0 & 75 & 25 \\
\hline
\end{tabular}

SL*: surface layer; $\mathrm{ML}^{*}$ : middle layer

Ammonium sulfate $\left[\left(\mathrm{NH}_{4}\right)_{2} \mathrm{SO}_{4}\right] 40 \%$ solution was used as a hardener at $2 \%$ in the middle layer and $1 \%$ in the surface layer. Experiments were conducted for the annual plants particle-boards to evaluate the effects of panel low density (500 versus $600 \mathrm{~kg} / \mathrm{m}^{3}$ ) and the resin types (UF, MUF and WP) (Table 2).

Ammonium sulfate $\left[\left(\mathrm{NH}_{4}\right)_{2} \mathrm{SO}_{4}\right] 40 \%$ solution was used as a hardener at $2 \%$ in the middle layer and $1 \%$ in the surface layer. Experiments were conducted for the annual plants particle-boards to evaluate the effects of panel low density (500 versus $600 \mathrm{~kg} / \mathrm{m}^{3}$ ) and the resin types (UF, MUF and WP) (Table 2).

Table 2. Particle board processing experimental design

\begin{tabular}{ll}
\hline Surface: core ratio & $40: 60$ \\
Resin type & Surface MUF + WP., core UF \\
Resin content, oven-dry chip mass basis & Surface $10 \%$, sore $8 \%$ \\
Surface layer material & $100 \%$ industrial wood chips \\
Middle layer material & $100 \%$ annual plants \\
Reference boards (surface and middle layer & $100 \%$ industrial wood chips \\
material) & \\
Pressing temperature & $200{ }^{\circ} \mathrm{C}$ \\
Pressing time & $15 \mathrm{~s} / \mathrm{mm}$ \\
Board dimension & $70 \mathrm{~cm} \mathrm{x} 46.5 \mathrm{~cm} \times 2 \mathrm{~cm}$ \\
Board thickness & $20 \mathrm{~mm}$ \\
Combinations & 24 variants, 3 repetitions each (72 total particle boards) \\
\hline
\end{tabular}


UF resin was applied in the core layer of all panels while $25 \%$ WP and $75 \%$ MUF resin were utilized in the face layers. The particleboard mats were pressed at a pressure of $220 \mathrm{bars}, 200^{\circ} \mathrm{C}$ for $5 \mathrm{~min}$ employing a lab scale hot press. Test specimens were $50 \times 50 \times 2 \mathrm{~cm}$. Panel physical properties were determined according to EN 312-2 (2003) standards, including: density profiles, water absorption and thickness swelling (EN 317), static bending strength (EN-310) and internal bond (EN-319), surface strength (EN-311).

\section{Results and Discussion}

There are several factors influencing the amount of chemical constituents in woody plant materials such as species, growth conditions, and time of year when they are harvested (Miller, 2002). In addition plant individuals, parts, tissue types, cell types and cell wall layers also have a big influence (Baucher et al., 1998).

In this study, despite the differentiation of source, all experimental substances were obtained from the plant stems. Some chemical compositions of two monocotyledons plants (bagasse and hemp) and a dicolyledons plant (canola) utilized in the study were determined (Table 3).

Table 3. The chemical composition of the annual plants and beech wood

\begin{tabular}{|c|c|c|c|c|}
\hline Chemical properties & Bagasse & Hemp & Canola & Beech \\
\hline & --------------- & - \% weight- & ----------- & -------------- \\
\hline Pentose & 12.47 & 15.52 & 17.36 & 13.4 \\
\hline Hemicellulose & 24.42 & 31.04 & 23.44 & 25.24 \\
\hline Lignin & 22.30 & 21.70 & 20.90 & 21.6 \\
\hline Hot water extractives & 6.60 & 9.03 & 8.60 & 4.4 \\
\hline Cold water extractives & 3.31 & 7.72 & 6.44 & 2.6 \\
\hline Ash content & 2.32 & 2.82 & 4.46 & 1.0 \\
\hline
\end{tabular}

A comparison between the three studied annual plants and beech wood indicates that the highest hemicellulose content was found for hemp (31\%) then bagasse with $24.4 \%$ (Table 3). Canola had the lowest hemicellulose value of $23.4 \%$. Hemicellulose plays an important role in fiber-to-fiber bonding in wood composite panels (Miller, 2002). The component sugars of hemicellulose are of high interest for conversion into chemical products as well (Miller, 2002).

In terms of lignin, bagasse had a higher content (22.3\%) compared to the other crop residues, close to the beech (21.6\%) and hemp (21.7\%) (Table 3). The 22.3\% lignin for hemp corresponds to that reported by Rasul et al. (1999). The highest extractives content was found in hemp $(9.03 \%$ via hot water method and $7.72 \%$ via cold water method) (Table 3).

Beech (a hard wood) had substantially lower extractives content compared to the annual plants (Table 3). Between the annual plants, the lowest extractives content existed in bagasse (hot water method $6.6 \%$ and cold water method $3.31 \%$ ).

This work demonstrates that different annual plants have different chemical compositions and amounts of extractives. Martunis (2008) reported that woody plants, both hard wood and soft wood, have lower extractives compared to annual plants, as was shown in this work for beech wood versus the three annual plant materials.

The inorganic component of extractives material is usually referred to as ash content. Canola had higher ash values (4.4\%) than the other materials in this study (Table 3). Hemp and bagasse are more or less similar in ash content, $2.8 \%$ to $2.3 \%$, respectively (Table 3 ). For the wood-based material beech the ash value was 1.0 percent (Table 3), which is in the range of $0.2 \%$ to $1 \%$ proposed by Miller (2002). 


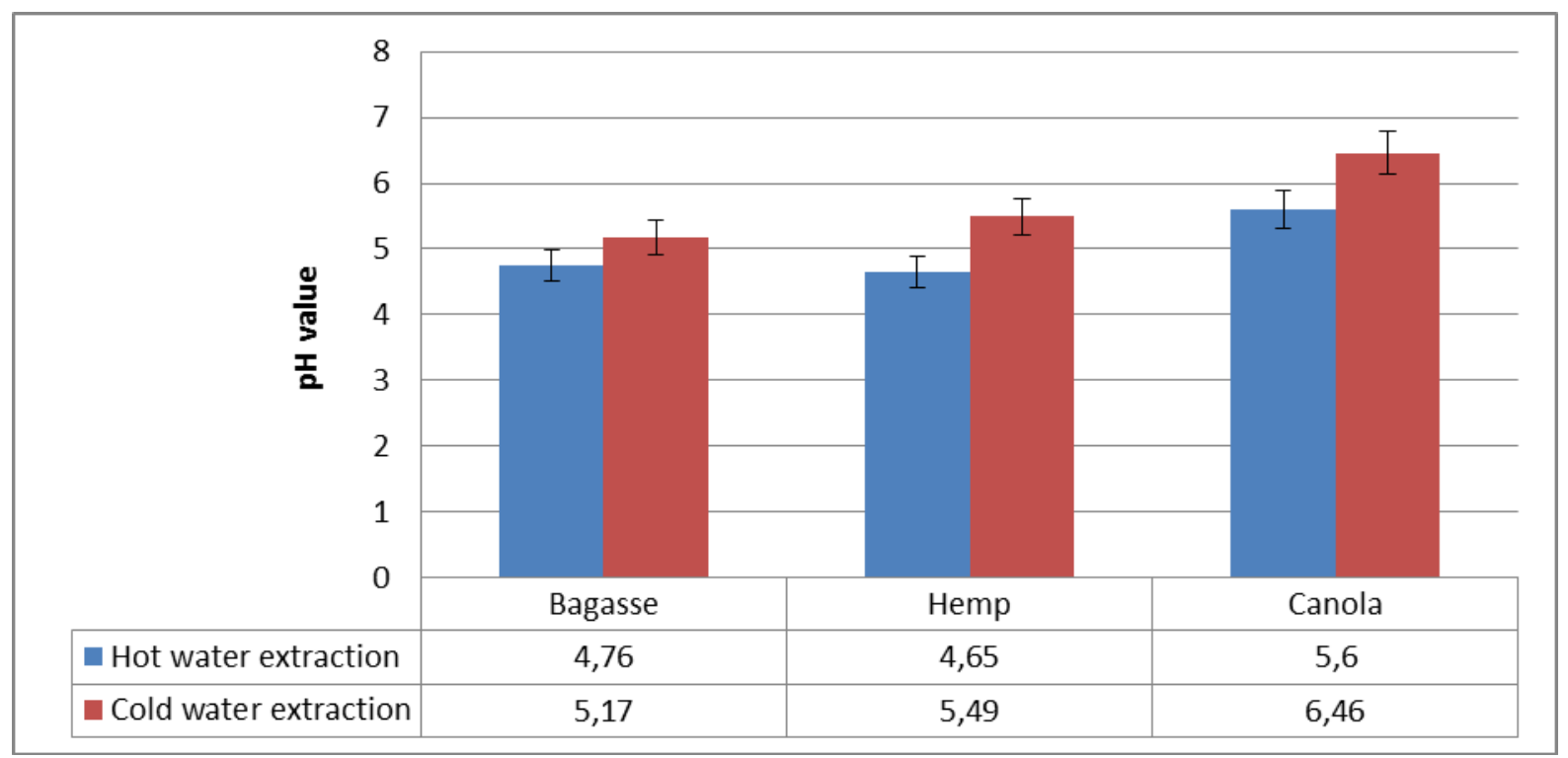

Figure 1. $\mathrm{pH}$ values of the annual plant materials

Chemical properties such as fiber $\mathrm{pH}$ and buffering capacity are two important factors influencing the curing rate of UF resin when wood-based particle board panels are pressed under heat. According to Johns and Niazi (1980) higher $\mathrm{pH}$ and lower base buffering capacity are always advisable, particularly, when UF resin is the binder. In Figure 1 and 2, $\mathrm{pH}$ and buffering capacity are showed. These factors may not be as important when using the annual plants or when applying WP as a bonding agent in particle board panels (Figure 1, Figure 2).

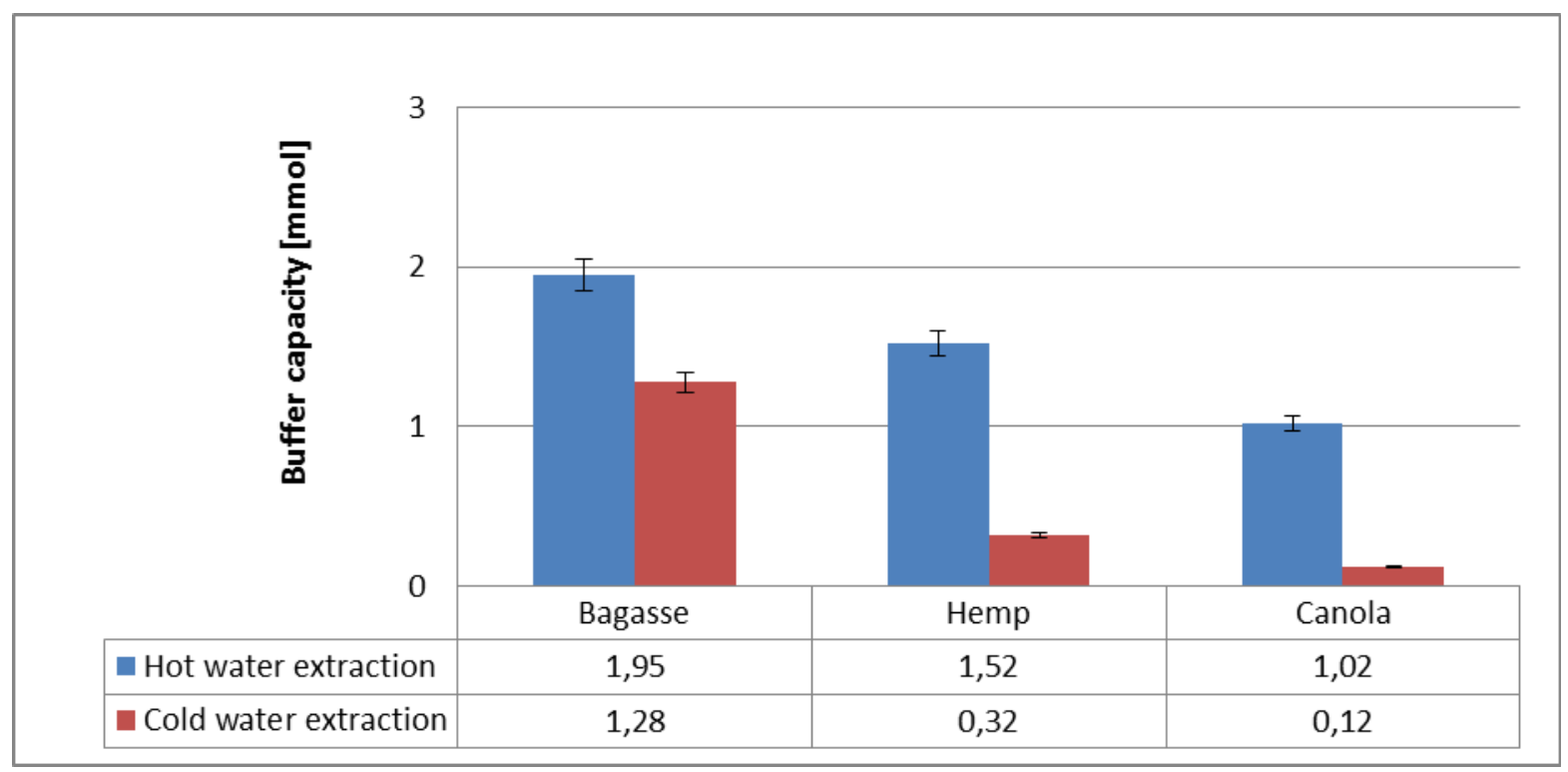

Figure 2. Buffer capacity values of three annual plant materials 
Table 4. The physical and mechanical properties of studied particle boards, as mean \pm sd values of the tested specimens

\begin{tabular}{|c|c|c|c|c|c|c|c|}
\hline \multicolumn{2}{|c|}{ Composition } & \multicolumn{6}{|c|}{ Coefficient of variation } \\
\hline Type & $\begin{array}{l}\text { Density } \\
\mathrm{kg} / \mathrm{m}^{3}\end{array}$ & $\begin{array}{c}\mathrm{MOE} \\
\mathrm{N} / \mathrm{mm}^{2} \\
(\mathrm{MPa})\end{array}$ & $\begin{array}{c}\mathrm{MOR} \\
\mathrm{N} / \mathrm{mm}^{2} \\
(\mathrm{MPa})\end{array}$ & $\begin{array}{c}\mathrm{IB} \\
\mathrm{N} / \mathrm{mm}^{2} \\
(\mathrm{MPa})\end{array}$ & $\begin{array}{c}\mathrm{AS} \\
\mathrm{N} / \mathrm{mm}^{2} \\
(\mathrm{MPa})\end{array}$ & WA $(24$ h) $(\%)$ & $\begin{array}{c}\text { TS (24 h) } \\
(\mathbf{\%})\end{array}$ \\
\hline $\begin{array}{l}\text { EN Standard } \\
\text { (20-mm thick } \\
\text { board) }\end{array}$ & -- & 1600 min. & $11 \mathrm{~min}$. & $0.35 \mathrm{~min}$ & $0.8 \mathrm{~min}$. & -- & 15 max. \\
\hline $\begin{array}{l}\text { Reference } \\
\text { wood panels } \\
-\end{array}$ & 0.502 & 1480 & 7.35 & 0.39 & 0.85 & 58 & 9.59 \\
\hline$-A * / 100$ & & & & & & & \\
\hline $\begin{array}{l}\mathrm{Ca} \\
\mathrm{Ba} \\
\mathrm{He}\end{array}$ & $\begin{array}{l}0.540 \pm 0.072 \\
0.545 \pm 0.091 \\
0.534 \pm 0.086\end{array}$ & $\begin{array}{l}1590 \pm 420.8 \\
2060 \pm 592.4 \\
2400 \pm 674.5\end{array}$ & $\begin{array}{r}6.6 \pm 1.67 \\
10.24 \pm 2.61 \\
11.15 \pm 3.04\end{array}$ & $\begin{array}{l}0.33 \pm 0.079 \\
0.36 \pm 0.082 \\
0.48 \pm 0.091\end{array}$ & $\begin{array}{l}0.76 \pm 0.132 \\
0.87 \pm 0.094 \\
0.88 \pm 0.118\end{array}$ & $\begin{array}{c}106.73 \pm 11.36 \\
73.03 \pm 9.57 \\
82.83 \pm 10.08 \\
\end{array}$ & $\begin{array}{r}21.1 \pm 3.24 \\
13.74 \pm 2.68 \\
15.3 \pm 3.53 \\
\end{array}$ \\
\hline $\begin{array}{l}\text { Reference } \\
\text { wood panels } \\
B^{* / 100}\end{array}$ & 0.627 & 2620 & 14.06 & 0.55 & 0.9 & 46.8 & 8.1 \\
\hline $\begin{array}{c}\mathrm{Ca} \\
\mathrm{Ba} \\
\mathrm{He}\end{array}$ & $\begin{array}{l}0.644 \pm 0.102 \\
0.637 \pm 0.098 \\
0.633 \pm 0.012\end{array}$ & $\begin{array}{l}2300 \pm 621.7 \\
3600 \pm 852.9 \\
3450 \pm 795.8 \\
\end{array}$ & $\begin{array}{r}8.15 \pm 2.11 \\
16.21 \pm 3.81 \\
17.27 \pm 4.23 \\
\end{array}$ & $\begin{array}{l}0.57 \pm 0.114 \\
0.67 \pm 0.098 \\
0.67 \pm 0.121 \\
\end{array}$ & $\begin{array}{l}0.75 \pm 0.096 \\
0.92 \pm 0.185 \\
0.94 \pm 0.144 \\
\end{array}$ & $\begin{array}{r}102.3 \pm 17.53 \\
71.7 \pm 15.21 \\
62.63 \pm 8.69 \\
\end{array}$ & $\begin{array}{r}21.46 \pm 3.21 \\
11.81 \pm 2.66 \\
13.7 \pm 3.61\end{array}$ \\
\hline
\end{tabular}

Modulus of elasticity (MOE), modulus of rupture (MOR), internal bond (IB), Surface stiffness or soundness (AS), water absorption (WA), and thickness swelling (TS).

min. $=$ minimum; max. $=$ maximum; Reference $=$ beech wood boards, $\mathrm{Ca}=$ canola, $\mathrm{Ba}=$ bagasse, and $\mathrm{He}=$ hemp $A^{*}$ : the boards with density $500 \mathrm{~kg} / \mathrm{m}^{3} ; \mathrm{B}^{*}$ : the boards with density $600 \mathrm{~kg} / \mathrm{m}^{3}$

The type and amount of bonding agent, one of the most important factors related to board strength, play an important roles in bending properties of particle boards. Both Group A $\left(500 \mathrm{~kg} / \mathrm{m}^{3}\right)$ and Group B $\left(600 \mathrm{~kg} / \mathrm{m}^{3}\right)$ (Table 4) reference (beech wood) boards in this study were bonded with $100 \%$ UF resin, whereas panels made of annual plants were bonded with a combined mixture of 75\% MUF resin and 25\% WP (at surface layers) and pure UF at middle (core) layers. The physical test results illustrate that panels bonded with MUF/WP resin obtained higher MOR values than those with the $100 \%$ UF resin. Thus, applying WP as a bonding agent in production of particleboard in this case will increase the MOR values. Only canola $\mathrm{Ca}-\mathrm{A} / 100$ and $\mathrm{Ca}-\mathrm{B} / 100$ showed less value (6.6 N/mm $\mathrm{mm}^{2}$ and $8.15 \mathrm{~N} / \mathrm{mm}^{2}$, respectively) compared to relative density references (beech wood). Bending stiffness or MOE of the boards was also observed. According to EN 310 the MOE is defined as a measure of stiffness of a material. The larger the e-module value, the less deformation of the material under load (Netuschil 2000). The different raw materials used in this study lead to different MOE values (Table 4), explaining the phenomenon in which panels made from hemp chips, with both $500 \mathrm{~kg} / \mathrm{m}^{3}$ and $600 \mathrm{~kg} / \mathrm{m}^{3}$ densities, obtained higher MOE values compared to those panels made from other plant materials or beech wood.

All of Group A $\left(500 \mathrm{~kg} / \mathrm{m}^{3}\right.$ density) annual plant boards in this work reached higher MOE values than the minimum requirement of the EN 312-2 (2003) Standard of $1.6 \mathrm{kN} / \mathrm{mm}^{2}$ (1600 MPa) for 20- mm panel thickness boards, except the canola CA-100 panels (Table 4). The MOE for canola CA-100 panels was not much lower than the EN Standard (1590 vs. 1600, respectively), but the study does indicate further research on panels Ca-100 have to be performed due to the lower e-module values.

Regarding the bending strength (MOR) and modulus of elasticity (MOE), all the boards in this study having densities of $600 \mathrm{~kg} / \mathrm{m}^{3}$ (Group B) met the minimum requirements of EN-312 Standard, except for the bending MOR of canola CA 100 which was only 8.1 MPA (Table 4). Hemp panels bonded with $75 \%$ MUF and $25 \%$ WP resin yielded higher bending strength and elasticity values than the other variants (Table 4).

Boards bonded with the combined mixture of MUF and WP resins achieved higher values compared to those of reference boards (100\% beech wood) bonded with of $100 \%$ UF resin (Table 4). Beside the glue types, panel 
density played a role, with Group B $\left(600 \mathrm{~kg} / \mathrm{m}^{3}\right.$ density) panels achieving higher MOE values compared to Group A (500 kg/m³ density) panels (Table 4). Internal bond (IB) strength of the panels showed that panel averages met the minimum required values according to the EN-319 (0.3 MPA), with canola boards having the lowest IB values (Table 4).

In the case of TS after $24 \mathrm{~h}$ immersion in water, all of the annual boards in the study met the minimum requirement of 20\% maximum, according the EN-317 (2003). However, panels made from canola yielded significantly higher TS values compared to the bagasse and hemp boards (Table 4, Figure 3). Additionally, the relation between density and TS performance showed that higher density panels yielded lower thickness swell values over the 24-h period compared to lower density panels, which is no doubt related to the increased water absorption values of the lower density panels. Canola boards absorbed more water compared to the others.

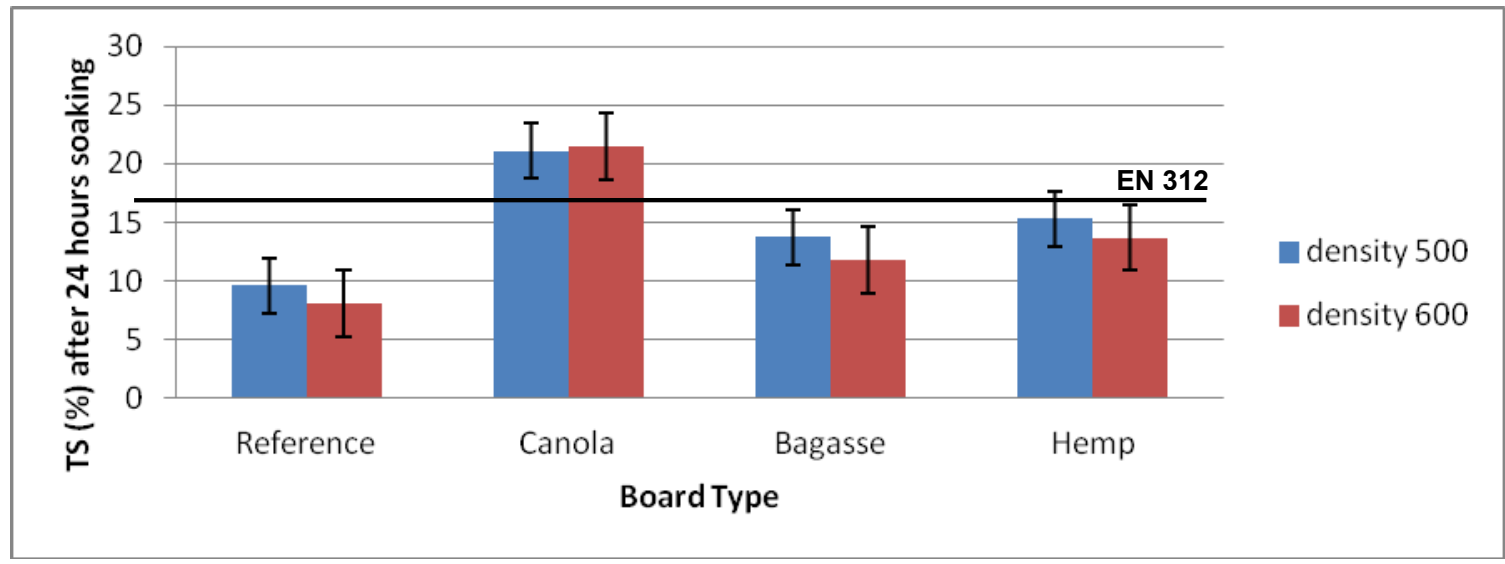

Figure 3. Comparison of thickness swelling of particle boards with densities 500 and $600 \mathrm{~kg} / \mathrm{m}^{3}$, containing bagasse, hemp and canola, each in mixture with wood (surface layer 100\% wood chips and middle layer $100 \%$ annual plant material) and references (100\% wood chips in surface and middle layer)

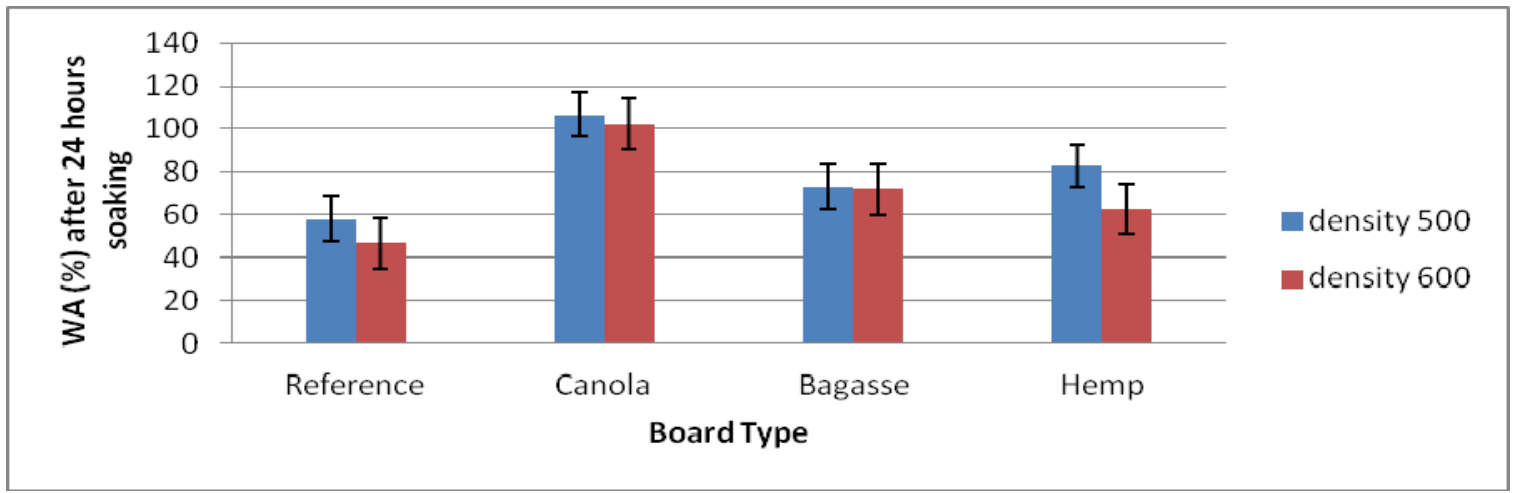

Figure 4. Comparison of water absorption of particle boards with densities 500 and $600 \mathrm{~kg} / \mathrm{m}^{3}$, containing bagasse, hemp and canola, each in mixture with wood chips (surface layer $100 \%$ wood chips and middle layer $100 \%$ annual plant material) and references (100\% wood chips in surface and middle layer)

While not shown in this report, the statistical results showed that the achieved densities among variant panels within a group for all the panels made with wood (reference boards) and hemp were within acceptable density variations of about $\pm 7 \%$, meeting the acceptable range according to the EN Standard. Whereas, the canola and bagasse $500 \mathrm{~kg} / \mathrm{m}^{3}$ density boards exceeded the acceptable range of density variation according to the EN Standard. 


\section{Conclusions}

This study has shown that the particle boards containing canola did not reach the requirements regarding the European Standards and require more study for acceptance. The reasons for warranting further study of canola is because canola is one of the most cultivated agro-plants in the world and its waste material should be a potential resource for the wood working industry. As alternative to MUF resin binder for the utilization of canola, hemp or bagasse in particle boards is the usage of polymeric methylene di-phenol isocyanate (pMDI) as bonding agent in combination with WP to improve the technological processing and mechanical and physical properties of panels. Another important aspect for future studies will also be the determination of volatile organic compound (VOC)-emissions of particle boards produced with canola, hemp and/or bagasse.

\section{References}

Baucher, M., Monties, B., van Montagu, M., \& Boerjan, W. (1998). Biosynthesis and genetic engineering of lignin. Critical Reviews in Plant Sciences, 17(2), 125-197. http://dx.doi.org/10.1016/S0735-2689(98)00360-8

Dewey, L. H. (1916). United States Department of Agricultural Bulletin No. 404: Hemp Hurds as Paper-Making Material. Retrieved October 14, 1916 from http://Hempology.org/img/BULLETIN\%20404.pdf

FAOSTAT. (1998). Food and Agricultural Organization of the United Nations Data Base. Retrieved October 14, 1916 from http://faostat.fao.org

Halse, O. M. (1926). Bestimmung von Zellstoff und Holzstoff im Papier. Papier-Journalen, 14(10), 121-123.

IUCN (International Union for Conservation of Nature). (1994). Analysis and Synthesis of National Reviews, IUCN European Program, Final report. The World Conservation Union, Gland.

Jayme, G., \& Büttel, H. (1968). Vergleich verschiedener Verfahren zur Pentosanbestimmung einschließlich einer neuen ISO-Methode. Das Papier, 22(5), 248-253.

Johns, W. E., \& Niazi, K. A. (1980). Effect of pH and buffering capacity of wood on the gelation time of urea-formaldehyde resin. Wood Fiber Sci., 12(4), 255-263.

Kalapathy, U., Hettiarachchy, N. S., \& Rhee, K. C. (1997). Effect of drying methods on molecular properties and functionalities of disulfide bond-cleaved soy proteins. Journal of the American Oil Chemists' Society Journal, 74(3), 195-199.

Lambuth, A. L. (1977). In Handbook of Adhesives (2nd ed. p 172). I. Skeist (Ed.), New York: Van Nostrand Reinhold.

Martunis, A. (2008). Utilization of grand fir for the production of medium density fiberboards in pilot scale (Master's Thesis). In the Faculty of Forest Sciences and Forest Ecology prepared on Büsgen-Institute Department of Molecular Wood Biotechnology and Technical Mycology, Georg-August-University, Göttingen, September 2008, p. 65.

McNutt, J. A., Haegglom, R., \& Raemoe, K. (1992). The global fiber resource picture. In Wood Product Demand and the Environment. A Forest Products Research Society International Conference Proceedings, 39-53.

Miller, R. B. (2002). Structure of Wood, Forest Products Laboratory, 1999, Wood Handbook-Wood as an Engineering Material. Gen. Tech. Rep. FPL-GTR-113. Madison, WI: U.S. Department of Agriculture, Forest Service, Forest Products Laboratory, p.463.

Milne, T., Brennan, A. H., \& Glenn, B. H. (1990). Sourcebook of Methods of Analysis for Biomass and Biomass (p.14). Colorado, USA: Elsevier Applied Science.

Netuschil, P. (2000). Charakterisierung der Oberfläche von Mitteldichten Faserplatten (MDF) (Dissertation). Fraunhofer- Institut für Holzforschung Wilhelm-Klauditz-Institut (WKI). WKI-Bericht Nr. 35

Nikvash, N., Kharazipour, A., \& Euring, M. (2012). Effects of wheat protein as a bio binder in the manufacture of particle boards using a mixture of canola, hemp, bagasse and commercial wood. Forest Prod J., 62(1), 49-57.

Nikvash, N., Kharazipour, A., \& Euring, M. (2013). Low density particleboards made with different kinds of annual plants and bonded with UF/wheat protein adhesives. Holztechnologie, 54(2), in Press.

Nikvash, N., Kraft R., Kharazipour, A., \& Euring, M. (2010). Comparative properties of bagasse, canola and hemp particle boards. Eur. J. Wood Prod., 68(3), 323-327. http://dx.doi.org/10.1007/s00107-010-0465-3

OECD (Organization for Economic Co-operation and Development). (2008). Preliminary Indicators of Eco-innovation in Selected Environmental Areas, Report for the Working Party on National Environmental Policies, 19-20 November ENV/EPOC/WPN. EP (2008)7, OECD, Paris (internal working document) 
Pizzi, A., Lipschitz, L., \& Valenzuela, J. (1994). Holzforschung, 48, 254. http://dx.doi.org/10.1515/hfsg.1994.48.3.254

Rasul, M. G., Rudolph, V., \& Carsky, M. (1999). Physical properties of bagasse. Fuel, 78, 905-9. http://dx.doi.org/10.1016/S0016-2361(99)00011-3

RCA. (2003). Agricultural residues, a promising alternative to virgin wood fiber. Resource Conservation Alliance (RCA), Washington, DC USA. Retrieved from http://www.woodconsumption.org/alts/meghanhayes.html

Roffael, E. (1993). Formaldehyde release from particle board and other wood based panels. Forest Research Institute Malaysia, Kepong, Kuala Lumpur, Malaysia.

Wikipedia. (2011). The Free Encyclopedia. Hemp. Retrieved from http://en.wikipedia.org/wiki/Hemp.

Zucaro, J., \& Reen, R. (1995). The second forest: filling the wood source gap while creating the environmental performance board of the 21st century, developing composites from wheat straw. 29th International Symposium on Particleboard/Composite Materials Pullman, WA, USA: Washington State University, p. 225-231. 